\title{
Analisis Pengaruh Program "Yuk Nabung Saham" oleh PT Bursa Efek Indonesia terhadap Minat Mahasiswa untuk Berinvestasi di Pasar Modal
}

\author{
Deara Shinta Lestari \\ STIE IBEK Pangkalpinang \\ lppmstieibekpangkalpinang@gmail.com
}

\begin{abstract}
Abstrak
Penelitian ini bertujuan untuk menginvestigasi pengaruh edukasi pasar modal, modal investasi minimal, dan return terhadap minat mahasiswa Mahasiswa STIE - IBEK Pangkalpinang yang terdaftar dan aktif di POEMS pada pasar modal. Jenis penelitian ini adalah kuantitatif deskriptif. Populasi nya adalah mahasiswa STIE -IBEK Pangkalpinang yang terdaftar dan aktif di POEMS. Metode pengambilan sampel yang digunakan adalah metode proportional test ratified random sampling. Teknik analisis data yang digunakan adalah regresi linier berganda, uji F, uji t, dan koefisien determinasi. Temuan penelitian menunjukkan bahwa variabel edukasi pasar modal, modal investasi minimal, dan return secara simultan dan parsial berpengaruh positif dan signifikan terhadap minat mahasiswa untuk berinvestasi di pasar modal.
\end{abstract}

Kata Kunci: Minat Investasi, Edukasi Pasar Modal, Modal Investasi Minimal dan Return

\section{Pendahuluan}

Pasar modal (capitalmarket)mempunyai peranan penting dalam pembangunan ekonomi suatu negara. Dengan adanya pasar modal investor individu maupun badan usaha dapat menyalurkan kelebihan dana yang dimilikinya untuk diinvestasikan di pasar modal, dan para pengusaha dapat memperoleh dana tambahan modal untuk memperluas jaringan usahanya dari para investor yang berada di pasar modal.

Pasar modal (capitalmarket) dibangun dengan maksud menggerakkan perekonomian suatu negara melalui swasta dan mengurangi beban negara. Negara memiliki kekuatan dan kekuasaan untuk mengatur bidang perekonomian dan tidak harus memiliki perusahaan sendiri. Di negara yang sudah maju, pasar modal menjadi sarana utama dalam pembangunan perekonomiannya. Negara maju tidak butuh badan usaha milik negara (BUMN), tetapi butuh usaha swasta yang profesional yang tercermin di pasar modal.(Sudirman, 2015: 5)

Hampir di seluruh negara di dunia ini memiliki pasar modal (capitalmarket) kecuali bagi negara-negara yang masih berbenah dan belum mampu melepaskan diri dari persoalan ekonomi dan politik yang begitu parah. Keberadaan pasar modal di suatu negara bisa menjadi acuan untuk melihat tentang bagaimana kegairahan atau dinamisnya bisnis negara yang bersangkutan dalam menggerakkan berbagai kebijakan ekonominya seperti kebijakan fiskal dan moneter.(Fahmi, 2013: 1). Tujuan dari PT. Bursa Efek Indonesia tidak semata fokus pada penambahan jumlah investor baru, namun juga berupaya untuk menanamkan kebutuhan berinvestasi di pasar modal, yang secara tidak langsung akan meningkatkan jumlah investor aktif di pasar modal Indonesia.

Yuk Nabung Saham (YNS) merupakan kampanye untuk mengajak masyarakat sebagai calon investor untuk berinvestasi di pasar modal dengan membeli saham secara rutin dan berkala. Kampanye ini dimaksudkan agar mengubah kebiasaan masyarakat Indonesia dari savingsociety(budaya menabung) menjadi investingsociety(budaya berinvestasi). Kampanye Yuk Nabung Saham ini sendiri diluncurkan pada tanggal 12 November 2015 oleh Wakil Presiden Republik Indonesia Bapak Muhammad Jusuf Kalla di Main Hall Gedung Indonesia 


\section{Stock Exchange.}

Teori yang digunakan dalam penelitian ini yang sekaligus menjadi acuan dalam penentuan variabel-variabel pada penelitian ini adalah Theory of Reasoned Action oleh Ajzen, (1985) yang dikutip dari penelitian(Merawati dan Putra, 2015), yang mana teori ini menyatakan bahwa perilaku seseorang ditentukan oleh suatu intensi. Intensi merupakan fungsi dari tingkah laku terhadap perilaku norma subjektif. Intensi ini ditentukan oleh tiga hal yaitu tingkah laku, norma subjektif dan pengendalian perilaku. Theory of Planned Behavior (pengembangan dari Theory of Reasoned Action) menyatakan bahwa dari ketiga hal yang menentukan intensi tersebut, tingkah laku merupakan poin utama yang mampu memprediksi sebuah perilaku. Karenanya niat berperilaku dapat menunjukkan perilaku yang akan dilakukan oleh seseorang. Hal ini dapat menjelaskan bahwa jika seorang yang memiliki minat berinvestasi maka kemungkinan besar dia akan melakukan tindakan-tindakan untuk dapat mencapai keinginannya berinvestasi, seperti mengikuti pelatihan dan seminar tentang investasi, menerima dengan baik penawaran investasi, dan pada akhirnya melakukan investasi. Selain itu pemahaman tentang return dari investasi dan modal investasi minimal dapat memudahkan seseorang untuk mengambil keputusan berinvestasi. Dalam melakukan investasi di pasar modal diperlukan pengetahuan yang memadai untuk menghindari terjadinya kerugian atau risiko saat berinvestasi.

\section{Telaah Literatur}

"Theory of Reasoned Action oleh Ajzen, (1985) dalam (Merawati dan Putra, 2015) menyatakan bahwa perilaku seseorang ditentukan oleh suatu intensi. Intensi merupakan fungsi dari tingkah laku terhadap perilaku norma subjektif. Intensi ini ditentukan oleh tiga hal yaitu tingkah laku, norma subjektif dan pengendalian perilaku. Theory of Planned Behavior (pengembangan dari Theory of Reasoned Action) menyatakan bahwa dari ketiga hal yang menentukan intensi tersebut, tingkah laku merupakan poin utama yang mampu memprediksi sebuah perilaku. Karenanya niat berperilaku dapat menunjukkan perilaku yang akan dilakukan oleh seseorang. Hal ini dapat menjelaskan bahwa jika seorang yang memiliki minat berinvestasi maka kemungkinan besar dia akan melakukan tindakan-tindakan untuk dapat mencapai keinginannya berinvestasi, seperti mengikuti pelatihan dan seminar tentang investasi, menerima dengan baik penawaran investasi, dan pada akhirnya melakukan investasi. Selain itu pemahaman tentang return dan modal investasi minimal dapat memudahkan seseorang untuk mengambil keputusan berinvestasi. Dalam melakukan investasi di pasar modal diperlukan pengetahuan yang memadai untuk menghindari terjadinya kerugian atau risiko saat berinvestasi.

\subsection{Saham}

Saham merupakan salah satu instrumen pasar modal yang paling diminati investor karena memberikan tingkat keuntungan yang menarik. Saham dapat didefinisikan sebagai tanda penyertaan modal seorang atau sepihak (badan usaha) dalam suatu perusahaan atau perseroan terbatas. Dengan menyertakan modal tersebut, maka pihak tersebut memiliki klaim atas pendapatan perusahaan, klaim atas aset perusahaan, dan berhak hadir dalam rapat umum pemegang saham (RUPS).

Menurut Husnan(2011: 29) pengertian saham adalah secarik kertas yang menunjukkan hak pemodal yaitu pihak yang memiliki kertas tersebut untuk memperoleh bagian dari prospek atau kekayaan organisasi yang menerbitkan sekuritas tersebut, dan berbagai kondisi yang memungkinkan pemodal tersebut menjalankan haknya. 
Menurut Darmadji dan Fachrudin (2012: 7), ada beberapa jenis saham yaitu:

a. Ditinjau dari segi kemampuan dalam hak tagih atau klaim, maka saham terbagi atas:

1) Saham biasa (common stock), yaitu merupakan saham yang menempatkan pemiliknya paling junior terhadap pembagian dividen, dan hak atas harta kekayaan perusahaan apabila perusahaan tersebut dilikuidasi.

2) Saham preferen (preferred stock), merupakan saham yang memiliki karakteristik gabungan antara obligasi dan saham biasa, karena bisa menghasilkan pendapatan tetap (seperti bunga obligasi), tetapi juga bisa tidak mendatangkan hasil seperti ini dikehendaki oleh investor.

b. Dilihat dari cara pemeliharaannya, saham dibedakan menjadi:

1) Saham atas unjuk (bearer stock) artinya pada saham tersebut tidak tertulis nama pemiliknya, agar mudah dipindahtangankan dari satu investor ke investor lain.

2) Saham atas nama (registered stock), merupakan saham yang ditulis dengan jelas siapa pemiliknya, dan dimana cara peralihannya harus melalui prosedur tertentu.

c. Ditinjau dari kinerja perdagangannya, maka saham dapat dikategorikan menjadi:

1) Saham unggulan (blue-chip stock), yaitu saham biasa dari suatu perusahaan yang memiliki reputasi tinggi, sebagai leader di industri sejenis, memiliki pendapatan yang stabil dan konsisten dalam membayar dividen.

2) Saham pendapatan (income stock), yaitu saham biasa dari suatu emiten yang memiliki kemampuan membayar dividen lebih tinggi dari rata-rata dividen yang dibayarkan pada tahun sebelumnya.

3) Saham pertumbuhan (growth stock-well known), yaitu saham-saham dari emiten yang memiliki pertumbuhan pendapatan yang tinggi, sebagai leader di industri sejenis yang mempunyai reputasi tinggi. Selain itu terdapat juga growth stock lesser known, yaitu saham dari emiten yang tidak sebagai leader dalam industri namun memiliki ciri growth stock.

4) Saham spekulatif (spekulative stock), yaitu saham suatu perusahaan yang tidak bisa secara konsisten memperoleh penghasilan yang tinggi di masa mendatang, meskipun belum pasti.

5) Saham siklikal (counter cyclical stock), yaitu saham yang tidak terpengaruh oleh kondisi ekonomi makro maupun situasi bisnis secara umum.

\section{2 Pasar Modal}

Pasar modal (capital market) merupakan pasar untuk berbagai instrumen keuangan jangka panjang yang bisa diperjualbelikan, baik surat utang (obligasi), ekuiti (saham), reksa dana, instrumen derivatif maupun instrumen lainnya. Pasar modal merupakan sarana pendanaan bagi perusahaan maupun institusi lain (misalnya pemerintah), dan sebagai sarana bagi kegiatan berinvestasi. Dengan demikian, pasar modal memfasilitasi berbagai sarana dan prasarana kegiatan jual beli dan kegiatan terkait lainnya.

Pengertian pasar modal menurut Undang-undang Pasar Modal Indonesia. 8 tahun 1995: "Pasar Modal yaitu sebagai suatu kegiatan yang bersangkutan dengan penawaran umum dan perdagangan efek, perusahaan publik yang berkaitan dengan efek yang diterbitkannya, serta lembaga dan profesi yang berkaitan dengan efek". (BEI, 2018) 
Pasar Modal memiliki peran penting bagi perekonomian suatu negara karena pasar modal menjalankan dua fungsi, yaitu pertama sebagai sarana bagi pendanaan usaha atau sebagai sarana bagi perusahaan untuk mendapatkan dana dari masyarakat pemodal (investor). Dana yang diperoleh dari pasar modal dapat digunakan untuk pengembangan usaha, ekspansi, penambahan modal kerja dan lain-lain, kedua pasar modal menjadi sarana bagi masyarakat untuk berinvestasi pada instrumen keuangan seperti saham, obligasi, reksa dana, dan lainlain. Dengan demikian, masyarakat dapat menempatkan dana yang dimilikinya sesuai dengan karakteristik keuntungan dan risiko masing-masing instrumen.

\subsection{Yuk Nabung Saham}

Yuk Nabung Saham (YNS) merupakan kampanye untuk mengajak masyarakat sebagai calon investor untuk berinvestasi di pasar modal dengan membeli Saham secara rutin dan berkala. Kampanye ini dimaksudkan agar mengubah kebiasaan masyarakat Indonesia dari kebiasaan menabung(saving society)menjadi kebiasaan berinvestasi (investing society). Kampanye Yuk Nabung Saham ini diluncurkan pada tanggal 12 November 2015 oleh Wakil Presiden Republik Indonesia Bapak Muhammad Jusuf Kalla di Main Hall Gedung Indonesia Stock Exchange.

Sebagai upaya dalam mengembangkan industri pasar modal di Indonesia, PT. Bursa Efek Indonesia (BEI) senantiasa mengedukasi dan mengembangkan industri ke arah yang lebih baik. Tujuan BEI tidak semata fokus pada penambahan jumlah investor baru, namun juga berupaya untuk menanamkan kebutuhan berinvestasi di pasar modal, yang secara tidak langsung akan meningkatkan jumlah investor aktif di pasar modal Indonesia.

Yuk Nabung Saham (YNS) adalah sebuah kampanye yang mengajak masyarakat Indonesia untuk berinvestasi di pasar modal melalui share saving. Dengan berbekal mulai dari Rp100.000 setiap bulan, masyarakat di ajak untuk menabung saham secara rutin dan berkala.

Program Yuk Nabung Saham ingin mengubah pola pikir masyarakat yang awalnya menabung harus ke bank menjadi menabung bisa pula ke pasar modal. Skema menabung saham juga hampir sama dengan menabung ke bank, yaitu masyarakat bisa menyisihkan sebagian dana (mulai dari Rp100.000) per bulan untuk menabung saham.

Produk dari Program Yuk Nabung Saham adalah saham dan reksadana yang rutin diinvestasikan tiap bulannya. Masing-masing perusahaan efek/sekuritas memiliki nama produk tabungan saham YNS yang berbeda-beda. Menabung saham dapat dilakukan dengan langkah-langkah sebagai berikut:

a. Memilih perusahaan sekuritas. Untuk memulai menabung saham di BEI maka harus memilih perusahaan sekuritas yang bekerjasama/menjadi partner YNS.

b. Membuka rekening efek/rekening saham. Seperti halnya menabung uang di bank, untuk menabung saham pun diperlukan membuka rekening efek di perusahaan sekuritas yang dipilih.

c. Tentukan nominal dana yang disisihkan untuk menabung saham.

d. Tentukan saham yang ingin ditabung.

e. Setor dana secara rutin.

Tidak ada syarat-syarat khusus dalam mengikuti program YNS ini, setiap orang, baik mahasiswa, ibu rumah tangga, dosen, guru dan semua profesi bisa mengikuti program YNS ini asalkan memiliki Kartu Tanda Penduduk terkait keperluan pembukaan rekening efek. 
Transaksi pembelian saham di program YNS dapat dilakukan secara autodebet melalui perusahaan efek/sekuritas yang telah memiliki produk tabungan saham, ataupun dengan mendatangi bank dan melakukan transaksi berkala kepada ke-43 anggota bursa yang telah menyediakan fitur Yuk Nabung Saham. Kedepannya, pemerintah akan mengupayakan agar jumlah perusahaan/sekuritas yang ikut serta dalam program Yuk Nabung Saham ini dapat bertambah sehingga dapat semakin memudahkan masyarakat yang ingin mengikuti program Yuk Nabung Saham.

\subsection{Edukasi Pasar Modal (EPM)}

Edukasi tentang pasar modal (EPM) kepada masyarakat adalah hal penting dalam melakukan aktivitas investasi. Edukasi pasar modal bertujuan agar masyarakat dan mahasiswa lebih mengetahui tentang pasar modal, memahami pentingnya berinvestasi, mengenal saham sebagai alat investasi yang ideal, memahami kendal-kendala sekaligus menarik minat masyarakat sebagai calon investor untuk berinvestasi di pasar modal Indonesia.

Edukasi dan sosialisasi kepada masyarakat di daerah-daerah untuk mendapatkan calon investor adalah langkah yang dilakukan pemerintah supaya menambah kontribusi masyarakat nantinya ke pasar modal. Pemerintah melalui campaign "Yuk Nabung Saham" diharapkan untuk terus mencetak investor-investor cerdas yang akan ikut serta membantu pertumbuhan pasar modal.

Investor Saham Pemula (ISP) merupakan komunitas sosial (socialcommunity) yang berfokus pada bidang edukasi pasar modal. Anggota Komunitas ISP tidak dikhususkan untuk kalangan pemuda-pemudi, namun untuk seluruh masyarakat Indonesia dari berbagai latar belakang dan usia. Komunitas ISP berusaha untuk terus berperan aktif dalam membantu masyarakat Indonesia agar melek investasi pasar modal, tidak hanya kalangan akademisi tapi juga masyarakat dari berbagai kelas. Galeri Investasi BEI juga sebagai pusat sosialisasi dan edukasi bagi masyarakat yang ingin berinvestasi di pasar modal serta juga menyediakan informasi tentang aktivitas perdagangan di pasar saham maupun instrumen pasar modal lainnya. Informasi dan data yang ada di Galeri Investasi BEI dapat digunakan oleh civitasakademika untuk tujuan akademik dan penelitian, di samping sebagai referensi dalam pengambilan keputusan saat melakukan transaksi jual dan beli Efek. Selain memberi informasi secara teoritis, di Galeri Investasi BEI masyarakat dan pihak kampus juga bisa praktik bagaimana melakukan transaksi di pasar saham.

Dengan adanya Galeri Investasi BEI diharapkan dapat saling memberikan manfaat bagi semua pihak sehingga penyebaran informasi pasar modal lebih tepat sasaran. Selain itu dapat memberikan manfaat yang optimal bagi mahasiswa, praktisi ekonomi, investor, pengamat pasar modal maupun masyarakat umum di daerah, baik untuk kepentingan edukasi dengan dilakukannya kegiatan sosialisasi pasar modal secara berkesinambungan maupun untuk kepentingan ekonomis atau sarana investasi.

\subsection{Modal Investasi Minimal (MIM)}

Investasi saham saat ini dapat dimulai dengan modal minim. Hal ini tentu akan membuat investasi saham jauh lebih terjangkau bagi masyarakat dari berbagai kalangan yang tidak punya banyak dana namun ingin berinvestasi. Bagi para pelajar dan mahasiswa, mereka dapat memulai investasi saham tanpa perlu khawatir dengan penggunaan modal yang besar, serta dapat dijadikan sebagai sarana pembelajaran.

Peraturan di PT. Bursa Efek Indonesia mengenai jumlah minimal pembelian saham dari suatu emiten (perusahaan yang menjual sahamnya ke publik) adalah sebanyak 1 lot $=100$ lembar 
saham. Sementara harga minimal saham yang diperdagangkan di BEI adalah Rp50 (lima puluh rupiah) per lembar saham.

Untuk mulai membeli saham setiap investor harus membuka rekening di sebuah sekuritas atau sering disebut broker, sebagai lembaga resmi yang menjadi perantara antara satu investor dengan investor lain. Setiap sekuritas/broker memiliki ketentuan masing-masing akan modal minimal yang harus dideposit ketika membuka rekening, saat ini di beberapa sekuritas dana awal yang harus disetor berkisar sebesar Rp100.000 (seratus ribu rupiah). Modal yang disetor ketika membuka rekening tidak harus dibelanjakan seluruhnya, beberapa saat setelah proses pembukaan rekening selesai, dapat mentransfer kembali sebagian dari modal yang disetor, dan menyisakan sejumlah yang ingin diinvestasikan saja.

\subsection{Return}

Tujuan investor dalam berinvestasi adalah untuk mendapat return, tanpa melupakan faktor risiko investasi yang harus dihadapinya. Menurut Fahmi (2013: 42)Return adalah keuntungan yang diperoleh perusahaan, individu dan institusi dari hasil kebijakan investasi yang dilakukannya. "Return merupakan salah satu faktor yang memotivasi investor berinvestasi dan juga merupakan imbalan atas keberanian investor menanggung risiko atas investasi yang dilakukannya".

Sumber-sumber return investasi terdiri dari dua komponen utama, yaitu yield dan capital gain (loss). Yield merupakan komponen return yang mencerminkan aliran kas atau pendapatan yang diperoleh secara periodik dari suatu investasi. Misalnya jika membeli saham, yield ditunjukkan oleh besarnya deviden yang diperoleh sedangkan, capital gain (loss) sebagai komponen kedua dari return merupakan kenaikan (penurunan) harga suatu surat berharga, yang bisa memberikan keuntungan (kerugian) bagi investor.

\section{Metode Penelitian}

\subsection{Desain Penelitian}

Penelitian ini merupakan penelitian kuantitatif. Teknik analisis yang digunakan dalam penelitian ini adalah menggunakan teknik analisis kuantitatif deskriptif dibantu dengan alat uji data menggunakan perangkat lunak yaitu JASP.Pengujian yang dilakukan dalam penelitian ini adalah menggunakan Analisis Statistik Deskriptif yang dimana didalam nya terdapat Uji Kualitas Data, Uji Validitas, Uji Reliabilitas. Selain itu peneliti akan melakukan Uji Asumsi Klasik yang dimana ada Uji Normalitas, Uji Multikolinearitas, Uji Heteroskedastisitas, selanjutnya peneliti akan melakukan Uji Regresi linier Berganda yang didalam nya terdapat Uji Hipotesis, Uji Parsial (Uji T), Uji Simultan (Uji F) dan Uji Koefisien determinasi $\left(\mathrm{R}^{2}\right)$ Pada intinya ialah sebagai alat ukur untuk mengukur seberapa besar kemampuan model dalam menjelaskan variasi variabel dependen.

\subsection{Populasi Penelitian}

Populasi dalam penelitian ini adalah Mahasiswa STIE - IBEK Pangkalpinang yang terdaftar dan aktif di POEMS dalam melakukan transaksi atau investasi di Pasar Modal. Pengambilan sampel dilakukan dengan metode proportiona test ratified random sampling yaitu pengambilan sampel yang digunakan jika populasi mempunyai anggota/unsur yang tidak homogen dan berstrata secara proporsional. (Sugiyono, 2016). Data yang digunakan pada penelitian ini adalah jenis data kuantitatif dari sumber data primer.

Penelitian ini menggunakan metode regresi berganda (multiple regression) dengan pengujian uji t-test dan f-test sebagai alat pengujian hipotesis antara variabel bebas dengan variabel 
terkaitnya. Disamping itu peneliti dalam penelitian ini juga menggunakan uji asumsi klasik untuk mendapatkan hasil penelitian yang baik. Jumlah sampel atau data responden yang akan digunakan dalam penelitian ini adalah data responden yang berupa jawaban kuesioner yang telah dikembalikan dan diterima secara lengkap oleh peneliti.

\subsection{Teknik Pengumpulan Data}

Penelitian ini merupakan penelitian kuantitatif. Teknik pengumpulan data yang digunakan dalam penelitian ini yaitu penggunakan kuesioner. Penggunaan kuesioner bertujuan untuk mendapatkan data primer dari responden. Data primer yang diperoleh diharapkan dapat memberikan gambaran terkini dari responden terhadap objek penelitian yang dilakukan. Penelitian ini menggunakan Teknik pengambilan sampel dalam penelitian ini yaitu menggunakan rumusSlovindengan tingkat presisi atau batas toleransi kesalahan pengambilan sampel sebesar 5\%.

\subsection{Uji Asumsi Klasik}

Penelitian ini bertujuan menguji pengaruh variabel independen terhadap suatu variabel dependen dengan mengunakan tiga variabel independen dan satu variabel dependen. Pengujian asumsi klasik merupakan persyaratan statistik yang harus dipenuhi pada regresi berganda. Namun demikian, tidak semua uji asumsi klasik dapat dilakukan kepada seluruh hubungan linier yang observasi. Uji asumsi klasik dalam penelitian ini menggunakan sejumlah pengujian yaitu: uji normalitas, uji multikolinieritas dan uji heteroskedastisitas, sedangkan uji autokerelasi tidak dilakukan karena penelitian ini tidak menggunakan data observasi yang bersifat runtut waktu (time series).

\subsection{Pengujian Instrumen Penelitian Pengujian Hipotesis.}

Hipotesis akan diuji dengan uji signifikansi satu sisi (one-tail test) dengan koefisien keyakinan sebesar 95\% atau menggunakan $\alpha=5 \%$. Apabila dalam pengujian ini ditemukan nilai probabilitas signifikan lebih kecil daripada $\alpha(5 \%)$, maka hipotesis nol (Ho) diterima, yang berarti bahwa variabel independen mempunyai pengaruh secara secara signifikan terhadap variabel dependen pada tingkat keyakinan $95 \%$.

\section{Hasil dan Pembahasan}

Berdasarkan hasil penelitian, maka didapat pembahasan sebagai berikut:

\subsection{Pengaruh edukasi pasar modal, modal investasi minimal dan return terhadap minat investasi mahasiswa}

Variabel edukasi pasar modal, modal investasi minimal dan return memiliki nilai signifikan sebesar 0,000 yang mana nilai tersebut lebih kecil dari 0,05 dan nilai Fhitung sebesar 3,864 yang mana nilai tersebut lebih besar dari nilai $\mathrm{f}_{\text {tabel }}$ sebesar 2,70 sehingga $\mathrm{H}_{1}$ diterima, artinya bahwa edukasi pasar modal, modal investasi minimal dan return secara bersama-sama berpengaruh dan signifikan terhadap minat mahasiswa STIE- IBEK Pangkalpinanguntuk berinvestasi di pasar modal.

Hasil penelitian ini sejalan dengan hasil penelitian yang dilakukan oleh Merawati dan Putra (2015) serta Tandio dan Widanaputra (2016) yang menunjukkan edukasi pasar modal melalui pelatihan pasar modal berpengaruh signifikan pada minat mahasiswa berinvestasi di pasar modal, hasil penelitian yang dilakukan oleh Nisa dan Zulaika (2017) juga menunjukkan modal investasi minimal berpengaruh signifikan pada minat mahasiswa berinvestasi di pasar modal serta penelitian yang dilakukan oleh Raditya et al. (2014) yang menunjukkan bahwa 
return berpengaruh signifikan pada minat mahasiswa untuk berinvestasi di pasar modal.

Tabel 4.1

\section{Coefficients $^{\mathrm{a}}$}

\begin{tabular}{|r|r|r|r|r|r|r|}
\hline Model & \multicolumn{1}{c|}{$\begin{array}{c}\text { Sum of } \\
\text { Squares }\end{array}$} & df & \multicolumn{1}{c|}{$\begin{array}{c}\text { Mean } \\
\text { Square }\end{array}$} & F & Sig. & F Tabel \\
\hline $1 \quad$ Regression & 36.923 & 2 & 18.462 & 3.864 &, $024^{\mathrm{b}}$ & \\
$\quad \begin{aligned} \text { Residual } \\
\text { Total }\end{aligned}$ & 439.561 & 92 & 4.778 & & & 2.70 \\
& 476.484 & 94 & & & \\
\hline
\end{tabular}

Sumber : Data Diolah, 2021

Hasil ini juga mendukung teori yang digunakan pada penelitian ini yaitu Theory of Reasoned Action yang menyatakan bahwa perilaku seseorang ditentukan oleh suatu intensi yang mana semakin seseorang sering mengikuti pelatihan pasar modal serta pemahaman akan modal investasi minimal dan return dari investasi maka minat untuk berinvestasi akan timbul. Edukasi bisa dilakukan dalam bentuk matakuliah, seminar-seminar investasi, pelatihan pasar modal, sosialisasi pasar modal maupun melalui galeri investasi yang memudahkan mahasiswa dalam mengambil keputusan untuk berinvestasi di pasar modal, bagi mahasiswa memulai berinvestasi dengan modal yang minimal memberikan kontribusi dalam mendorong minat mahasiswa untuk berinvestasi di pasar modal, serta pemahaman akan return dalam berinvestasijuga merupakan salah satu faktor yang memotivasi mahasiswa untuk berinvestasi di pasar modal.

Tabel 4.2

ANOVA ${ }^{\mathrm{a}}$

\begin{tabular}{|c|r|r|c|c|c|}
\hline \multirow{2}{*}{ Model } & \multicolumn{2}{|c|}{$\begin{array}{c}\text { Unstandardized } \\
\text { Coefficients }\end{array}$} & $\begin{array}{c}\text { Standardized } \\
\text { Coefficients }\end{array}$ & $\mathrm{t}$ & Sig. \\
\cline { 2 - 5 } & $\mathrm{B}$ & $\begin{array}{c}\text { Std. } \\
\text { Error }\end{array}$ & Beta & \\
\hline $1 \quad \begin{array}{l}\text { (Constant) } \\
\begin{array}{l}\text { Total_Edukasi Pasar } \\
\text { Modal_Modal Investasi } \\
\text { Minimal_return }\end{array}\end{array}$ & -.158 & .057 & -.279 & -2.768 & .007 \\
\hline
\end{tabular}

4.2 Pengaruh edukasi pasar modal terhadap minat investasi mahasiswa

Variabel edukasi pasar modal memiliki nilai signifikan sebesar 0,000 yang mana nilai tersebut lebih kecil dari 0,05 dan nilai thitung sebesar 16,894 yang mana nilai tersebut lebih besar dari nilai tabel sebesar 1,986 sehingga $\mathrm{H}_{2}$ diterima, artinya bahwa edukasi pasar modal berpengaruh dan signifikan terhadap minat mahasiswa STIE- IBEK Pangkalpinang untuk 
berinvestasi di pasar modal.

Tabel 4.3

Coefficients $^{\mathrm{a}}$

\begin{tabular}{|l|r|r|r|r|r|}
\hline \multirow{2}{*}{ Model } & \multicolumn{2}{|c|}{$\begin{array}{l}\text { Unstandardized } \\
\text { Coefficients }\end{array}$} & $\begin{array}{c}\text { Standardized } \\
\text { Coefficients }\end{array}$ & Sig. \\
\cline { 2 - 6 } & \multicolumn{1}{|c|}{$\mathrm{B}$} & Std. Error & Beta & \\
\hline $1 \quad$ (Constant) & 21.637 & 1.281 & & 16.894 & .000 \\
$\begin{array}{l}\text { Total_Edukasi } \\
\text { Pasar Modal }\end{array}$ & -.239 & .078 & -.312 & -3.055 & .003 \\
\hline
\end{tabular}

Sumber : Data Diolah, 2021

Hasil penelitian ini sejalan dengan hasil penelitian yang dilakukan oleh Merawati dan Putra (2015) serta Tandio dan Widanaputra (2016) yang menunjukkan bahwa edukasi pasar modal melalui pelatihan pasar modal berpengaruh signifikan pada minat mahasiswa berinvestasi, namun hasil ini juga bertentangan dengan hasil penelitian dari Nisa dan Zulaika (2017) yang menunjukkan bahwa pemahaman mengenai investasi tidak memiliki pengaruh terhadap minat mahasiswa untuk berinvestasi di pasar modal, hal ini menunjukkan bahwa materi mengenai manajemen investasi dan pasar modal yang memberi pemahaman mahasiswa mengenai pengertian investasi, jenis investasi, keuntungan investasi serta risiko berinvestasi tidak dipertimbangkan oleh mahasiswa untuk menjadi investor di pasar modal.

\section{Tabel 4.4}

ANOVA ${ }^{\mathrm{a}}$

\begin{tabular}{|c|c|c|c|c|c|c|c|}
\hline \multicolumn{2}{|c|}{ Model } & \multirow{2}{*}{$\begin{array}{r}\begin{array}{c}\text { Sum of } \\
\text { Squares }\end{array} \\
44.182\end{array}$} & & \multirow{2}{*}{$\begin{array}{l}\begin{array}{c}\text { Mean } \\
\text { Square }\end{array} \\
22.091\end{array}$} & \multirow{2}{*}{$\frac{F}{4.701}$} & \multirow{2}{*}{$\frac{\text { Sig. }}{, 011^{\mathrm{b}}}$} & T Tabel \\
\hline 1 & Regression & & & & & & \\
\hline & Residual & 432.302 & 92 & 4.699 & & & 1.986 \\
\hline & Total & 476.484 & 94 & & & & \\
\hline
\end{tabular}

Sumber : Data Diolah, 2021

Hasil ini juga mendukung teori yang digunakan pada penelitian ini yaitu Theory of Reasoned Action yang menyatakan bahwa perilaku seseorang ditentukan oleh suatu intensi yang mana semakin seseorang sering mengikuti pelatihan pasar modal maka minat untuk berinvestasi akan timbul. Edukasi mengenai pasar modal penting untuk memberikan pemahaman kepada mahasiswa tentang investasi. Edukasi mengenai pasar modal yang diperoleh mahasiswa memberikan kontribusi dalam mendorong minat berinvestasi. Edukasi ini bisa dilakukan dalam bentuk matakuliah, seminar-seminar investasi, pelatihan pasar modal, sosialisasi pasar modal maupun melalui galeri investasi ternyata memudahkan mahasiswa dalam mengambil 
keputusan untuk berinvestasi di pasar modal.

\subsection{Pengaruh modal investasi minimalterhadap minat investasi mahasiswa}

\section{Tabel 4.5}

\section{Coefficients $^{\mathrm{a}}$}

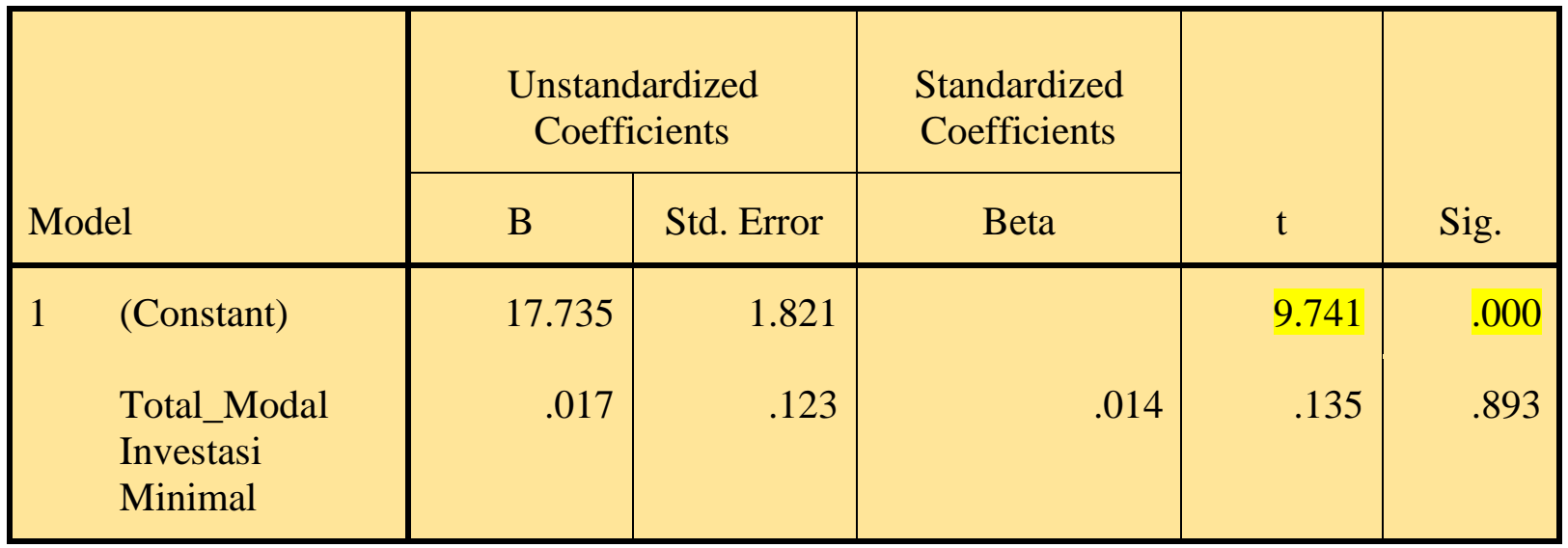

Sumber : Data Diolah, 2021

Variabel modal investasi minimal terhadap minat investasi memiliki nilai signifikan sebesar 0,000 yang mana nilai tersebut lebih kecil dari 0,05 dan nilai thitung sebesar 9,741 yang mana nilai tersebut lebih besar dari nilai tabel sebesar 1,986 sehingga $\mathrm{H}_{3}$ diterima, artinya bahwa modal investasi minimal berpengaruh dan signifikan terhadap minat mahasiswa STIE- IBEK Pangkalpinanguntuk berinvestasi saham.

Tabel 4.6

ANOVA ${ }^{\mathrm{a}}$

\begin{tabular}{|c|c|c|c|c|c|c|c|}
\hline \multicolumn{2}{|c|}{ Model } & $\begin{array}{l}\text { Sum of } \\
\text { Squares }\end{array}$ & df & $\begin{array}{l}\text { Mean } \\
\text { Square }\end{array}$ & $\mathrm{F}$ & Sig. & T Tabel \\
\hline \multirow[t]{3}{*}{1} & Regression & .417 & 2 & .209 & .040 &, $960^{b}$ & \\
\hline & Residual & 476.067 & 92 & 5.175 & & & 1,986 \\
\hline & Total & 476.484 & 94 & & & & \\
\hline
\end{tabular}

Hasil penelitian ini sejalan dengan hasil penelitian yang dilakukan oleh Nisa dan Zulaika (2017) yang menunjukkan modal investasi minimal berpengaruh signifikan pada minat mahasiswa berinvestasi, namun hasil ini juga bertentangan dengan hasil penelitian dari Raditya et al. (2014) yang menunjukkan bahwa modal investasi minimal tidak berpengaruh terhadap minat mahasiswa untuk berinvestasi di pasar modal, hal ini karena investor sepertinya memiliki faktor lain yang lebih penting untuk dipertimbangkan, misalnya penghasilan, return atau risiko yang memang terbukti berpengaruh pada minat investasi.

Hasil ini juga mendukung teori yang digunakan pada penelitian ini yaitu Theory of Reasoned Action yang menyatakan bahwa perilaku seseorang ditentukan oleh suatu intensi yang mana semakin seseorang paham akan modal investasi minimal dan modal awal yang digunakan 
untuk berinvestasi relatif murah maka minat untuk berinvestasi akan timbul. Modal investasi minimal dengan dana awal yang harus disetor berkisar sebesar Rp 100.000,- dan jumlah minimal pembelian saham dari suatu emiten (perusahaan yang menjual sahamnya ke publik) adalah sebanyak 1 lot = 100 lembar ternyata memudahkan dalam mengambil keputusan untuk berinvestasi. Bagi mahasiswa memulai berinvestasi dengan modal yang minimal memberikan kontribusi dalam mendorong minat mahasiswa untuk berinvestasi di pasar modal.

\subsection{Pengaruh return terhadap minat investasi mahasiswa}

\section{Tabel 4.7}

\section{Coefficients ${ }^{\mathrm{a}}$}

\begin{tabular}{|l|r|r|r|r|r|}
\hline \multirow{2}{*}{ Model } & \multicolumn{2}{|c|}{$\begin{array}{c}\text { Unstandardized } \\
\text { Coefficients }\end{array}$} & $\begin{array}{c}\text { Standardized } \\
\text { Coefficients }\end{array}$ & \\
\cline { 2 - 6 } & $\mathrm{B}$ & $\begin{array}{c}\text { Std. } \\
\text { Error }\end{array}$ & Beta & $\mathrm{t}$ & Sig. \\
\hline $1 \quad$ (Constant) & 19.966 & 1.445 & & 13.820 & .000 \\
Total_return & -.201 & .138 & -.150 & -1.458 & .148 \\
\hline
\end{tabular}

Sumber : Data Diolah, 2021

Variabel return memiliki nilai signifikan sebesar 0,000 yang mana nilai tersebut lebih kecil dari 0,05 dan nilai thitung sebesar 13,820 yang mana nilai tersebut lebih besar dari nilai tabel sebesar 1,986 sehingga $\mathrm{H}_{4}$ diterima, artinya return berpengaruh dan signifikan terhadap minat mahasiswa STIE- IBEK Pangkalpinanguntuk berinvestasi di pasar modal.

Tabel 4.8

ANOVA ${ }^{a}$

\begin{tabular}{|c|c|c|c|c|c|c|c|}
\hline \multicolumn{2}{|c|}{ Model } & $\begin{array}{l}\text { Sum of } \\
\text { Squares }\end{array}$ & df & $\begin{array}{l}\text { Mean } \\
\text { Square }\end{array}$ & $\mathrm{F}$ & Sig. & $\mathrm{T}$ Tabel \\
\hline 1 & Regression & .417 & 2 & .209 & .040 &, $960^{\mathrm{b}}$ & \\
\hline & Residual & 476.067 & 92 & 5.175 & & & 1,986 \\
\hline & Total & 476.484 & 94 & & & & \\
\hline
\end{tabular}

Sumber : Data Diolah, 2021

Hasil penelitian ini sejalan dengan penelitian yang dilakukan oleh Raditya et al. (2014) serta (Tandio dan Widanaputra, 2016) yang menunjukkan bahwa return berpengaruh signifikan pada minat mahasiswa untuk berinvestasi di pasar modal.

Hasil ini juga mendukung teori yang digunakan pada penelitian ini yaitu Theory of Reasoned Action yang menyatakan bahwa perilaku seseorang ditentukan oleh suatu intensi yang mana 
semakin seseorang paham akan return dalam berinvestasi maka minat untuk berinvestasi akan timbul Tujuan investor dalam berinvestasi adalah memaksimalkan return, tanpa melupakan faktor risiko investasi yang harus dihadapinya. Return merupakan hasil yang diperoleh dari investasi. Return juga merupakan salah satu faktor yang memotivasi investor berinvestasi, sehingga return memberikan kontribusi dalam mendorong mahasiswa untuk berinvestasi.

\section{Kesimpulan}

Berdasarkan hasil pengolahan data yang telah dijabarkan pada bab sebelumnya, dengan demikian dapat ditarik kesimpulan mengenai hasil penelitian ini sebagai berikut:

1. Edukasi pasar modal, modal investasi minimal dan return secara bersama-sama berpengaruh positif dan signifikan terhadap minat mahasiswa untuk berinvestasi di pasar modal.

2. Edukasi pasar modal berpengaruh positif dan signifikan terhadap minat mahasiswa untuk berinvestasi di pasar modal.

3. Modal investasi minimal berpengaruh positif dan signifikan terhadap minat mahasiswa untuk berinvestasi di pasar modal.

4. Return berpengaruh positif dan signifikan terhadap minat mahasiswa untuk berinvestasi di pasar modal.

\section{Saran}

Berdasarkan kesimpulan dan keterbatasan dalam penelitian ini, maka dapat diberikan saran untuk penelitian selanjutnya:

1. Edukasi pasar modal, modal investasi minimal dan return hanya merupakan beberapa variabel bebas yang mempengaruhi variabel minat investasi mahasiswa yaitu hanya $53,9 \%$, ini berarti masih terdapat variabel bebas lain yang bisa mempengaruhi minat investasi mahasiswa.

2. Bagi peneliti berikutnya dapat menambah variabel lain seperti motivasi, risiko, umur, dan penghasilan.

3. Penelitian ini hanya dilakukan di Fakultas Ekonomi Universitas Indo Global Mandiri. Untuk penelitian selanjutnya diharapkan dapat dilakukan pada seluruh Fakultas di lingkungan Universitas Indo Global Mandiri atau bahkan dilakukan penelitian di beberapa Universitas yang ada di kota Palembang.

\section{Referensi}

Aziz, M., Mintarti, S., dan Nadir, M. 2015. Manajemen Investasi. Bandung: Alfabeta.

BEI. 2018. Pengantar Pasar Modal. https://www.idx.co.id/investor/pengantar-pasar-modal/. Diakses pada 22 September 2019.

BEI. 2017. Yuk Nabung Saham. http://yuknabungsaham.idx.co.id/about-yns. Diakses pada 22 September 2019

Darmadji, T., dan Fachrudin. 2012. Pasar Modal Di Indonesia. In Salemba Empat (Ketiga). Jakarta: Salemba Empat

Djali. 2013. Psikologi Pendidikan. Jakarta: PT. Bumi Aksara. 
Fahmi, I. 2013. Rahasia Saham Dan Obligasi strategi meraih keuntungan tak terbatas dalam bermain saham dan obligasi. Bandung: Alfabeta.

Husnan, S. 2011. Manajemen Keuangan Teori dan Penerapan. Yogyakarta: BPFE.

Khotimah, H. 2014. Pengaruh Sosialisasi dan Pengetahuan Terhadap Minat Investor Pada Efek Syariah di Pasar Modal (Survei Pada Nasabah PT Danareksa Sekuritas Cabang FE-UI Depok) Husnul Khotimah. 423-433.

Merawati, L. K., dan Putra, I. P. M. J. S. 2015. Kemampuan Pelatihan Pasar Modal Memoderasi Pengaruh Pengetahuan Investasi Dan Penghasilan Pada Minat Berinvestasi Mahasiswa. Jurnal Ilmiah Akuntansi Dan Bisnis.

Nisa, A., dan Zulaika, L. 2017. Pengaruh Pemahaman Investasi, Modal Minimal Investasi Dan Motivasi Terhadap Minat Mahasiswa Berinvestasi Di Pasar Modal. Jurnal PETA, 2 (2), $22-35$.

Rafsanjani. 2018. Analisis Program Yuk Nabung Saham Terhadap Minat Mahasiswa Untuk Berinvestasi di Pasar Modal Syariah (Studi pada Mahasiswa Universitas Islam Negeri Raden Intan Lampung).

Sudirman. 2015. Pasar Modal dan Manajemen Portofolio (2nd ed.). Jakarta: PT. Gelora Aksara Pratama.

Sugiyono. 2011. Metode Penelitian Kombinasi. Bandung: Alfabeta.

Tandio, T., dan Widanaputra, A. 2016. Pengaruh Pelatihan Pasar Modal, Return, Persepsi Risiko, Gender, Dan Kemajuan Teknologi Pada Minat Investasi Mahasiswa. E-Jurnal Akuntansi, 16 (3), 2316-2341. 